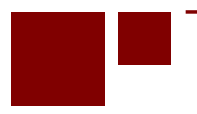

C E N T E R for

RETIREMENT

RE S E A R C H

at BOSTON COLLEGE

\title{
THE CONSEQUENCES OF CURRENT BENEFIT ADJUSTMENTS FOR EARLY AND DELAYED CLAIMING
}

\author{
Andrew G. Biggs, Anqi Chen, and Alicia H. Munnell \\ CRR WP 2021-3 \\ January 2021
Center for Retirement Research at Boston College
Hovey House
140 Commonwealth Avenue \\ Chestnut Hill, MA 02467
}

Tel: 617-552-1762 Fax: 617-552-0191

https://crr.bc.edu

\begin{abstract}
Andrew G. Biggs is a resident scholar at the American Enterprise Institute. Anqi Chen is assistant director of savings research at the Center for Retirement Research at Boston College (CRR). Alicia H. Munnell is director of the CRR and the Peter F. Drucker Professor of Management Sciences at Boston College's Carroll School of Management. The research reported herein was derived in whole or in part from research activities performed pursuant to a grant from the U.S. Social Security Administration (SSA) funded as part of the Retirement and Disability Research Consortium. The opinions and conclusions expressed are solely those of the authors and do not represent the opinions or policy of SSA, any agency of the federal government, the American Enterprise Institute, or Boston College. Neither the United States Government nor any agency thereof, nor any of their employees, make any warranty, express or implied, or assumes any legal liability or responsibility for the accuracy, completeness, or usefulness of the contents of this report. Reference herein to any specific commercial product, process or service by trade name, trademark, manufacturer, or otherwise does not necessarily constitute or imply endorsement, recommendation or favoring by the United States Government or any agency thereof.
\end{abstract}

(C) 2021, Andrew G. Biggs, Anqi Chen, and Alicia H. Munnell. All rights reserved. Short sections of text, not to exceed two paragraphs, may be quoted without explicit permission provided that full credit, including $\odot$ notice, is given to the source. 


\begin{abstract}
About the Center for Retirement Research
The Center for Retirement Research at Boston College, part of a consortium that includes parallel centers at the National Bureau of Economic Research, the University of Michigan, and the University of Wisconsin-Madison, was established in 1998 through a grant from the U.S. Social Security Administration. The Center's mission is to produce first-class research and forge a strong link between the academic community and decision-makers in the public and private sectors around an issue of critical importance to the nation's future. To achieve this mission, the Center conducts a wide variety of research projects, transmits new findings to a broad audience, trains new scholars, and broadens access to valuable data sources.
\end{abstract}

Center for Retirement Research at Boston College

Hovey House

140 Commonwealth Ave

Chestnut Hill, MA 02467

Tel: 617-552-1762 Fax: 617-552-0191

https://crr.bc.edu

Affiliated Institutions:

The Brookings Institution

Mathematica - Center for Studying Disability Policy

Syracuse University

Urban Institute 


\begin{abstract}
Workers have the option of claiming Social Security retirement benefits at any age between 62 and 70, with later claiming resulting in higher monthly benefits. These higher monthly benefits reflect an actuarial adjustment designed to keep lifetime benefits equal, for an individual with average life expectancy, regardless of when benefits are claimed. The actuarial adjustments, however, are decades old. Since then, interest rates have declined; life expectancy has increased; and longevity improvements have been much greater for high earners than low earners. This paper explores how changes in longevity and interest rates have affected the fairness of the actuarial adjustment over time and how the disparity in life expectancy affects the equity across the income distribution. It also looks at the impact of these developments on the costs of the program and the progressivity of benefits.
\end{abstract}

The paper found that:

- The increases in life expectancy and the decline in interest rates argue for smaller reductions for early claiming and a smaller delayed retirement credit for later claiming.

- Specifically, the benefit at 62 should equal 77.5 percent, as opposed to 70.0 percent, of the full age-67 benefit, and the benefit at 70 should equal 119.9 percent, instead of 124.0 percent, of the full benefit.

- The outdated actuarial adjustments are a modest moneymaker for the program - about $\$ 1.9$ billion in 2018, with most of the gains coming from those claiming at 62 , who are typically lower earners. Surprisingly, the correlations between earnings and life expectancy and between earnings and claiming behavior have only modest implications for both the cost and progressivity of Social Security benefits.

- Finally, the cost and distributional effects of earnings-related life expectancy and claiming cannot be addressed through the actuarial adjustments for early and late claiming. They reflect the fact that high earners get their large benefits for a long time and low earners get their more modest benefits for a shorter time.

The policy implications of the findings are:

- Increases in life expectancy and the decline in interest rates suggest smaller reductions for early claiming and a smaller delayed retirement credit for later claiming. 
- Accounting for differential mortality would involve changing benefits, and is not a problem that can be solved by tinkering with the actuarial adjustments. 


\section{Introduction}

Workers in the United States have the option of claiming Social Security retirement benefits at any age between 62 and 70, with later claiming resulting in higher monthly benefits. These higher benefits reflect an actuarial adjustment designed to keep lifetime benefits equal, for an individual with average life expectancy, regardless of when benefits are claimed. The actuarial adjustments, however, are decades old.

The option to claim early was introduced over 60 years ago, when Congress set 62 as the program's "Earliest Age of Eligibility." Those claiming at 62 receive 20 percent less in monthly benefits than if they had claimed at 65 . The option to claim between 65 and 70 on an actuarially fair basis stems from the 1983 Social Security Amendments, which gradually increased the annual "delayed retirement credit" from 3 percent to 8 percent. Much has changed since these actuarial adjustments were introduced.

Life expectancy has increased steadily over the decades. Increases in longevity mean that people receive benefits for a longer period of time, so the percentage increase in lifetime benefits from early claiming - without an actuarial reduction - is smaller. This smaller percentage increase suggests that a smaller reduction for early claiming would be required to keep lifetime benefits constant across claiming ages.

The appropriate actuarial adjustment also depends on interest rates. An increase in rates reduces the cost of benefits paid at age 65 more than those paid at 62 , which would call for a larger actuarial adjustment to equalize lifetime benefits across claiming ages. Conversely, a decline in rates would require a smaller actuarial adjustment for early claiming. Prior to 2000, rising interest rates offset the increase in life expectancy, so adjustments for claiming at different ages were roughly actuarially fair (Jivan 2004; Munnell and Sass 2012; Highland and Yin 2014). After 2000, the low interest rate environment reinforced the effect of continued increases in longevity and made the reduction for early claiming too large (Duggan and Soares 2002; Shoven and Slavov 2014a). Comparable effects apply to the appropriate size of the delayed retirement credit (Coile et al. 2002; Munnell and Soto 2005; Sass, Sun, and Webb 2007; and Meyer and Reicherstein 2010). ${ }^{1}$

\footnotetext{
${ }^{1}$ Rule changes in the 1990s and early 2000s have also favored delayed claiming. For example, previously, a nonearning spouse had to wait until the earning spouse claimed to receive retirement benefits. After 2000, married couples could claim spousal benefits as long as the earning spouse reached their FRA, regardless of whether they have claimed.
} 
Even if the actuarial adjustment for early and late claiming were perfect for workers with average life expectancy, the dispersion in life expectancy raises equity issues across the earnings distribution. High-earning workers, who enjoy the longest life expectancy, receive their relatively large benefits for a long period of time regardless of claim age, and they get an overly generous benefit increase when they delay because the adjustment is calculated to keep costs and lifetime benefits equal for the average worker. Similarly, lower earners are hurt because they are more likely to claim early (U.S. Social Security Administration 2019d) and, due to the dispersion in life expectancy across income quintiles, receive their smaller than actuarially fair benefit for fewer years (Chetty et al. 2016; Tan 2019; Burtless 2014; Case 2015; Goda et al. 2011; Cutler 2011; Waldron 2007; and Armour 2004). ${ }^{2}$ This pattern has implications for both program costs and the progressivity of the benefit structure (Garrett 1995; Meyerson and Sabelhaus 2005; Bosworth et al. 2014; and Auerbach et al. 2017). ${ }^{3}$ While dispersion in life expectancy has increased in recent years, the longevity of high earners has always exceeded that of low earners and considering benefits on a lifetime rather than an annual basis sharply reduces the progressivity of the retirement portion of the Social Security program (Gustman and Steinmeier 2001; Coronado et al. 2011; and Bosworth, Burtless, and Zhang 2016). This persistent pattern cannot be mitigated, however, through tinkering with the actuarial adjustment.

The paper explores how changes in longevity and interest rates have affected the fairness of the actuarial adjustment over time and how the disparity in life expectancy affects the equity across the income distribution. It also looks at the impact of these developments on the costs of the program and the progressivity of benefits.

The discussion proceeds as follows. The first section provides a brief history of the Social Security benefit adjustments. The second section explores the extent to which increasing life expectancy for the average worker and declining interest rates would call for smaller reductions for early claiming and a smaller delayed retirement credit for later claiming. It presents a schedule for actuarially fair adjustments and summarizes the costs (or savings) to the system of maintaining outdated adjustments. The third section moves away from the average

\footnotetext{
${ }^{2}$ For example, Chetty et al. (2016) found that, those in the top 5 percent of the income distribution saw life expectancy gains of around three years from 2001 to 2014, while those in the bottom 5 percent experienced no gains.

${ }^{3}$ It also affects the progressivity based on marital status. For example, the penalty is larger for married couples because claiming early reduces not only the retirement benefit but also spousal and survivor benefits. The penalty is also larger for single woman relative to single men because of longer life expectancies (Duggan and Soares 2002; Shoven and Slavov 2014a; and Shoven and Slavov 2014b).
} 
worker to address the cost and equity implications of the fact that life expectancy and claiming behavior are both positively correlated with earnings. The final section concludes with four findings.

These findings are as follows. First, the increases in life expectancy and the decline in interest rates argue for smaller reductions for early claiming and a smaller delayed retirement credit for later claiming. Specifically, the benefit at 62 should equal 77.5 percent, as opposed to 70.0 percent, of the full age-67 benefit, and the benefit at 70 should equal 119.9 percent, instead of 124.0 percent, of the full benefit. Second, the outdated actuarial adjustments are a modest moneymaker for the program - about $\$ 1.9$ billion in 2018 , with most of the gains coming from those claiming at 62, who are typically lower earners. Third, surprisingly, the correlations between earnings and life expectancy and between earnings and claiming behavior have only modest implications for both the cost and progressivity of Social Security benefits. For the current population of beneficiaries, earnings-related mortality increases the cost of lifetime benefits by 3.6 percent over a system where mortality across earnings quintiles is assumed to be constant. Interestingly, earnings-related claiming slightly decreases the cost of lifetime benefits (roughly 0.6 percent) because a substantial portion of high earners claim early and receive a larger actuarial adjustment than their life expectancy would warrant. Finally, the cost and distributional effects of earnings-related life expectancy and claiming cannot be addressed through the actuarial adjustments for early and late claiming. They reflect the fact that high earners get their large benefits for a long time and low earners get their more modest benefits for a shorter time. Addressing this issue would require a reassessment of the benefit structure - a topic far beyond the scope of this paper.

\section{Background on Social Security Benefit Adjustments}

The original legislation creating the Social Security program did not allow workers to claim benefits before the program's eligibility age of 65 and provided no incentive to claim later. The flexibility to claim at any age between 62 and 70 emerged in two spurts of legislation roughly 20 years apart. 


\section{The Ability to Claim Before 65}

In 1956, Congress gave women the option to retire as early as age 62, albeit on a reduced monthly benefit to account for the additional years over which they would receive benefits. The new option was designed to allow married women, who were typically the younger member of the couple, to retire and claim benefits at the same time as their husbands. ${ }^{4}$ Congress made the option available to all women, so as not to discriminate against unmarried women. Congress extended this option to men in 1961, during a recession that made early retirement an attractive policy response.

Congress reduced the monthly benefit for early claimers to "closely approximate an 'actuarial-equivalent' basis, so that no additional cost to the system arises on account of early retirement." ${ }^{5}$ That is, for a woman with average life expectancy, Congress intended the cost of lifetime benefits to be much the same whether she claimed benefits at 62 or 65 . Based on interest rates at the time, the benefit reduction factor for claiming at 62 was determined to be 20 percent - roughly 6.7 percent per year. ${ }^{6}$ The same adjustment factor was applied to men, despite differences in life expectancy.

\section{An Incentive to Claim After 65}

The ability to claim after 65 on an actuarially fair basis was adopted later and implemented more gradually. This delayed retirement credit was introduced in 1972 at 1 percent per year up to age 72 (later reduced to age 70), increased to 3 percent by the 1977 Amendments, and scheduled by the 1983 Amendments to increase gradually to 8 percent for those attaining age 65 in 2008. The first column of Table 1 shows what the actuarial adjustment factors would have looked like at ages 62-70 if nothing else had changed - a reduction of 6.7 percent for three years before 65 and an increase of 8 percent for each year after 65 .

\footnotetext{
${ }^{4}$ The 1948 Advisory Council Report on Social Security recommended lowering the age that women could start receiving benefits to 60 .

${ }^{5}$ Myers (1993).

${ }^{6}$ For administrative convenience, the benefit reduction for early retirement was set at $5 / 9$ of 1 percent for each month a participant claimed before 65 (5/9 percent per month $\times 36$ months $=20$ percent $)$.
} 


\section{Impact of Increase in Full Retirement Age}

The schedule for early and delayed claiming also has been impacted by the gradual increase from 65 to 67 in the Full Retirement Age (FRA), the age at which workers receive their base benefit amount as determined by their work and earnings history. In Table 1, this base benefit is set equal to $1.000 .{ }^{7}$ The changes in the benefit factors as the FRA increases largely reflect moving this reference point from 1.000 for age 65 (for those born before 1938) to 1.000 for age 66 (for those born between 1938-1959) and then 67 (for those born after 1959). As before, benefits are reduced by 6.7 percent for three years before the FRA and increased by 8 percent for each year after the FRA. In addition, benefits are reduced by 5 percent per year if claimed more than three years before the FRA. These percentage reductions mean that someone retiring at 62 will continue to receive 80 percent of the age- 65 benefit. Thus, despite a lot of changes, the actuarial adjustment factors have remained relatively constant over several decades.

\section{Impact of Life Expectancy and Interest Rates on Actuarial Adjustments}

While the benefit adjustment factors have not changed in decades, longevity has increased and interest rates have declined. Both factors would be expected to affect the actuarial fairness of the adjustment.

Life Expectancy. Increases in longevity mean that people receive benefits for a longer period of time, so the percentage increase in lifetime benefits from early claiming - without an actuarial reduction - is smaller (see Figure 1). For example, average life expectancy for a woman at 65 is now 21.6 years - about five years longer than in $1956 .^{8}$ In 1956, a woman who claimed at 62 instead of 65 and collected benefits for three additional years - without any adjustment - would have increased her lifetime benefits by about 18 percent (3.0/16.9). ${ }^{9}$ Today, with life expectancy at 21.6, participants who claim at 62 instead of 65 today would increase their lifetime benefits by 14 percent (3.0/21.6). This smaller percentage increase suggests that a

\footnotetext{
${ }^{7}$ The base monthly benefit - the Primary Insurance Amount (PIA) - is calculated by applying a progressive formula to the monthly average of the highest 35 years of earnings over a worker's career.

${ }^{8}$ The mortality data used in determining Social Security's current actuarial reductions for early claiming excluded individuals who were already receiving Social Security disability benefits (who tend to have lower life expectancy). As a result, life expectancy estimates from these data are somewhat higher than the life expectancy data for the general population cited in this brief. See Goss (1985).

${ }^{9}$ In 1956 , cohort life expectancy at 65 was 13.1 years for men and 16.9 years for women. See U.S. Social Security Administration (2019a).
} 
smaller reduction for early claiming would be required to keep costs constant across claiming ages. Similarly, longer life expectancies would call for a smaller delayed retirement credit.

Interest Rates. The appropriate actuarial adjustment also depends on interest rates, because they determine the amount the government must put aside to pay future benefits. The following discussion focuses on the interest rate for the special-issue bonds held by the Social Security Trust Fund, but other interest rates produce a similar story. ${ }^{10}$ Adjusted for inflation, the interest rate on these bonds was relatively flat in the 1960s and 1970s, rose sharply in the early 1980s and has declined sharply since then (see Figure 2).

A decline in the interest rate increases the cost of benefits claimed at any age - that is, it increases the amount that the government would have to put aside at 62 for benefits claimed at both ages 62 and 65 . But, because the rate decline affects interest on larger balances in the case of later claiming, it increases the cost of benefits paid at age 65 more than those paid at 62 . Thus, to keep it actuarially fair, the interest rate effect on early claiming would call for a slight reduction in the age-62 benefit, given that real interest rates in 2020 are only slightly lower than they were in 1960.

In terms of delayed claiming, the issue is similar. A lower interest rate increases the cost of benefits beginning at both 65 and 70, but it increases the cost of benefits that begin at 70 more than those beginning at 65 . Thus, the interest rate effect would call for a smaller delayed retirement credit.

In short, longer life expectancy and lower interest rates work in the same direction. In both cases, reducing the penalty for early claiming and the reward for later claiming would better align the costs of early and late claiming.

\section{How Far Off Are the Benefit Factors for the Average Worker?}

The first step in the analysis is to look at how low interest rates and average mortality affect program costs, before layering on the effect of mortality inequality and examining how it

\footnotetext{
${ }^{10}$ The special-issue bonds are only available to the Trust Fund, have a duration between one and 15 years, and can always be redeemed at par. See U.S. Social Security Administration (2019b) for the interest rates earned on these bonds. An alternative rate would be the long-run interest rate assumptions used in the annual Social Security Trustees Report. Long-run interest rate assumptions are less volatile, but market interest rates, as used in the analysis, are useful in conveying the current experience of individuals approaching retirement. Both methods yield similar results.
} 
affects both program costs and progressivity. The reason for this dual focus is that policymakers may have an interest in simply adjusting the current reductions and credits - which are constant across earners - or, alternatively, in adjusting the system in a more comprehensive way to reflect mortality inequality.

To evaluate the appropriateness of today's actuarial adjustments requires comparing the cost to the system of early or late claiming. The cost is equal to the expected present value of future benefits:

$$
E P V_{c}=\sum_{a=62}^{120} \frac{s_{a} S S_{c}}{(1+r)^{a-62}} * I(a \geq c)
$$

where $c$ is the claiming age being used to calculate the EPV; $r$ is the interest rate; $a$ is the age at which the benefit is received; $s_{a}$ is the probability of a person surviving to age $a ; S S_{c}$ is the estimated average Social Security benefit for claiming at age $c$; and $I(a \geq c)$ indicates whether the benefit has been claimed as of age $a$. Data on survival probabilities and interest rates come from unpublished data from the Social Security actuaries. As indicated, interest rates are annual returns on Trust Fund assets, adjusted for inflation. ${ }^{11}$ If the costs to the system of early and late claiming are equal, then the ratio will equal 1.

The easiest place to start is the ratio of costs for claiming at 62 versus claiming at 65 . Figure 3 shows that this ratio was close to 1.0 in 1960, fluctuated significantly in the 1970 s and early 1980s, then declined steadily from the mid-1980s to the present. In 2020, the ratio is expected to be 0.94 , which means that the cost of benefits for the early claimant is only 94 percent of the cost of benefits for the individual who claims at 65. The implication is that the reduction for early retirement is too large and that reducing it would bring the costs at 62 and 65 closer together.

The next step is to compare claiming at 65 to claiming at 70 - assuming no change in the FRA. Thus, this calculation is hypothetical because: 1) the Full Retirement Age was increasing from 65 to 67; and 2) it assumes the full 8-percent delayed retirement credit, which was not available until 2008, was in place throughout the period. The results in Figure 4 show that

\footnotetext{
${ }^{11}$ Interest rates are adjusted for inflation using the CPI-W. See footnote 10 for more information on special-issue bonds held by Social Security.
} 
initially the cost to the government of an individual claiming at 65 significantly exceeded that of an individual claiming at 70. In other words, the delayed retirement credit of 8 percent was too small to equalize the costs of claiming at 70 versus 65. Indeed, Robert Myers, the former chief actuary of Social Security, characterized 8 percent as "not much less than the true actuarial equivalent (about 9 percent)."12 As life expectancy has increased and interest rates have declined, the costs to the government of an individual claiming at 65 and at 70 have narrowed so that today the ratio is at 0.99 .

The final step is to compare the ratio of lifetime benefits claimed at 62 to lifetime benefits claimed at 70, incorporating movement in the FRA from 65 to 67 . Figure 5 shows that this ratio has declined steadily since 1990 and claiming at 62 costs the system only 90 percent of claiming at age 70. Thus, for individuals with average life expectancy, the reduction for early claiming is too large.

The data underlying Figure 5 can be used to calculate actuarially fair adjustments for early and late claiming. Table 2 reports the adjustments under current law - assuming an FRA of 67 - and adjustments that would keep lifetime benefits equal regardless of claiming age. To achieve this aim, monthly benefits at age 62 would need to be increased from 0.700 of the full benefit to 0.775 - roughly an 8 -percent increase. At the same time, the age-70 adjustment would need to be reduced from 1.240 of the full benefits to 1.199 - roughly a 3 -percent reduction. ${ }^{13}$

The data can also be used to estimate the cost to the system of the current versus actuarially fair adjustments (see Table 3). The calculation involves multiplying the dollar difference between actuarially fair monthly benefits and current benefits for each claiming age by the number of beneficiaries. Annualizing that amount shows that using the unfair actuarially adjustments saves the Social Security system about $\$ 1.9$ billion per year. And the great bulk of that saving comes from those retiring at age 62 .

The key takeaway from this analysis is that, for the individual with average life expectancy, the real problem is that the penalty for early claiming is too large rather than the increase for claiming later. The question is how the divergence in life expectancy factors into the analysis.

\footnotetext{
12 Myers (1993).

${ }^{13}$ Appendix Table A1 shows the sensitivity of these "fair" actuarial adjustment factors to different assumed long-run interest rates. While the factors differ depending on the interest rate, the story remains the same: the percentage of the full benefit paid at 62 is currently too small and the percentage of the full benefit paid at 70 is too large.
} 


\section{How Does the Dispersion in Mortality Affect the Picture?}

Life expectancy has always varied by income. For example, the death rate on the Titanic for First Class passengers was 38 percent, for Second Class passengers 56 percent, and for those in Steerage 75 percent. ${ }^{14}$ The life expectancy disparity has important implications for Social Security. ${ }^{15}$ To clarify the issues, it is helpful to first consider a world where the only difference between high earners and low earners is life expectancy before considering that claiming behavior is also linked to earnings.

A recent study from the Office of the Chief Actuary at Social Security is particularly useful for examining the impact of the correlation between life expectancy and earnings. Specifically, the actuaries studied the relationship - by age and sex - between average indexed monthly earnings (AIME) - a measure of lifetime earnings - and mortality rates for retired worker beneficiaries ages 62 and over, using the Master Beneficiary Record. The actuaries drop beneficiaries affected by the Windfall Elimination Provision and Totalization Agreements because the AIMEs for these individuals do not represent their true career average earnings; they also drop retired workers who were previously eligible for disability benefits because they generally have a shorter work history. They carry out their analysis for every fifth year from 1995 through 2015.

The results are presented in terms of relative mortality rates by AIME, where 1.00 indicates that the death rate for an AIME group was the same as the average for that sex and age group as a whole. Generally, higher AIME levels are associated with lower mortality for both males and females. For example, in 2015, the relative death rate for males 65-69 in the lowest AIME quintile was 1.63 compared to 0.54 for the highest AIME quintile (see Table 4). The story for women could be slightly different because historically they worked less consistently in paid employment and therefore their personal earnings (as summarized by the AIME) may not accurately represent their economic status. Nevertheless, female workers generally follow the same relative mortality pattern as males, in that higher earners have lower mortality.

While much of the recent discussion about life expectancy has focused on the increasing dispersion over time, the actuaries show a relatively modest increase in the dispersion of death rates among the AIME levels from 1995 to 2015 (see Figure 6 for males ages 62-64).

\footnotetext{
${ }^{14}$ See Henderson (1998).

${ }^{15}$ For a survey of the literature see on this topic through the early 2000s, see Waldron (2007). And for a more recent study, see Chetty et al. (2016).
} 
Translating the death rates into life expectancies confirms that the magnitude of the increase is not as large as reported in some recent studies (see Figure 7). ${ }^{16}$ This pattern probably reflects the fact that the actuaries are looking at life expectancy at 62 rather than at 50, and the dispersion of death rates across AIME levels tends to diminish as the cohort ages and the healthiest individuals survive (see Figure 8).

The impact of the correlation between earnings and mortality can be shown by comparing the outcomes assuming that all beneficiaries have the same mortality - or at least one where mortality rates vary randomly across AIME quintiles - to the situation documented by the actuaries where AIME and mortality are highly correlated.

The first set of calculations, which assumes all workers claim at age 62 - and therefore receive 77.5 percent of their full benefit, shows the impact of having earnings-related mortality (see Table 5). The most obvious change is that the lifetime benefits of the worker in the lowest quintile declines, while the benefit for the worker in the highest quintile increases. Second, the increase in benefits for high earners far exceeds the reduction for low earners and thereby raises the combined cost of lifetime benefits for the five workers representing the five quintiles.

The second set of calculations expands the claiming ages to include all years between 62 and 70 (see Table 6). Three patterns emerge. First, the total cost across the five workers increases regardless of claiming age, mainly because the actuarial adjustment for high earners is inadequate to compensate for the additional years that they receive benefits. Second, with earnings-related mortality, the actuarial adjustment no longer keeps costs the same regardless of claiming age. And third, low earners lose lifetime benefits from delay, while high earners gain.

The final set of calculations account for not only earnings-related mortality but also earnings-related claiming. Data from the Health and Retirement Study linked to administrative benefits data show that high earners - for whom the actuarial adjustments are too generous tend to claim later while low earners - for whom the actuarial adjustments are too punitive - tend to claim earlier (see Figure 9). Importantly for the discussion below, however, despite the tendency for high-earners to claim later than their low-earning counterparts, 37 percent in the highest quintile claim at 62 .

\footnotetext{
${ }^{16}$ Auerbach et al. (2017), using the HRS, found that life expectancy at age 50 among those in the lowest quintile of lifetime earnings remained unchanged between the cohorts born in the 1930s and 1950s. Those in the highest lifetime income quintile, however, saw an increase in life expectancy at age 50 of over 7 years between the same cohorts. However, an earlier study by Waldron (2007) predicted differences in life expectancy at age 65 that are similar to the differences found in this analysis.
} 
Table 7 shows the total cost of lifetime benefits for all retired workers currently receiving benefits under: 1) the assumption of constant mortality; 2) the actual pattern of earnings-related mortality documented by the actuaries; and 3) actual earnings-related mortality and actual earnings-related claiming. The earnings-related mortality pattern increases costs by 3.6 percent. On the other hand, earnings-related claiming reduces the costs slightly ( 0.6 percent) because a substantial portion of high earners also claim early and receive a larger reduction than their life expectancy would warrant. Overall, the combined earnings-related factors increase the costs by 3 percent (from $\$ 14.2$ billion to $\$ 14.7$ billion).

Finally, Table 8 shows the impact of earnings-related patterns on progressivity as measured by the distribution of benefits among the AIME quintiles. Incorporating the earningsrelated factors increases the share of benefits going to the high earners from 32 percent to 34 percent, while reducing the share going to the bottom quintile from 9 percent to 8 percent.

The key question is the extent to which these undesirable outcomes can be remedied by altering the actuarial adjustment to account at least for earnings-related mortality. One notion might be to calculate separate actuarial adjustments to reflect the mortality in each quintile. This approach, however, would produce an unwanted pattern. Low earners with shorter life expectancies would face even higher actuarial reductions than the average worker for early claiming, while high earners with long life expectancies would enjoy smaller reductions for early claiming - albeit also smaller increases for delayed claiming. Another approach might be to explicitly incorporate in the actuarial adjustment the additional (or fewer) years of life expectancy relative to the average for workers in each quintile. Such a calculation would require the additional constraints that: 1) workers receive 100 percent of their benefits at age 67 - the assumed Full Retirement Age; and 2) the cost to the system remains constant across claiming ages. The product of this calculation is illuminating. While it is possible to generate numbers that satisfy these constraints, they involve higher benefit levels for low earners and lower benefit levels for high earners. That is, the basic problem is that high earners receive high benefits and low earners receive low benefits. It is not a problem that can be solved by tinkering with the actuarial adjustment. 


\section{Conclusion}

The paper explores how changes in longevity and interest rates have affected the fairness of the actuarial adjustment over time and how the disparity in life expectancy affects the equity across the income distribution. It also looks at the impact of these developments on the costs of the program and the progressivity of benefits.

It produced four findings. First, the increases in life expectancy and the decline in interest rates argue for smaller reductions for early claiming and a smaller delayed retirement credit for later claiming. Specifically, the benefit at 62 should equal 77.5 percent, as opposed to 70.0 percent, of the full age 67 benefit, and the benefit at 70 should equal 119.9 percent, instead of 124.0 percent, of the full benefit.

Second, the outdated actuarial adjustments are a modest moneymaker for the program about $\$ 1.9$ billion per year in 2018 , with most of the gains coming from those claiming at 62 , who are typically lower earners.

Third, it turns out that the correlations between earnings and life expectancy and between earnings and claiming behavior have relatively modest implications for both the cost and progressivity of Social Security benefits. For the current population of beneficiaries, earningsrelated mortality increases the cost of lifetime benefits by 3.6 percent over a system where mortality was constant across earnings quintiles. Interestingly, earnings-related claiming slightly decreases the cost of lifetime benefits (roughly 0.6 percent) because a substantial portion of high earners claim early and receive a larger actuarial adjustment than their life expectancy would warrant.

The final conclusion is that the cost and distributional effects of earnings-related life expectancy and claiming cannot be addressed through the actuarial adjustments for early and late claiming. They reflect the fact that high earners get their large benefits for a long time and low earners get their more modest benefits for a shorter time. Addressing this issue would require a reassessment of the benefit structure - a topic far beyond the scope of this paper. 


\section{References}

Advisory Council on Social Security. 1949. Recommendations for Social Security LegislationThe Reports of the 1948 Advisory Council on Social Security. $80^{\text {th }}$ Congress, $2^{\text {nd }}$ Session, Senate Document No. 208. Washington, DC: U.S. Government Printing Office. Available at: https://www.ssa.gov/history/reports/48advisegen.html

Auerbach, Alan J., Kerwin K. Charles, Courtney C. Coile, William Gale, Dana Goldman, Ronald Lee, Charles M. Lucas et al. 2017. "How the Growing Gap in Life Expectancy May Affect Retirement Benefits and Reforms." The Geneva Papers on Risk and InsuranceIssues and Practice 42(3): 475-499.

Bosworth, Barry, Gary Burtless, and Kan Zhang. 2016. "Later Retirement, Inequality in Old Age, and the Growing Gap in Longevity Between Rich and Poor.” Working Paper 87. Washington, DC: The Brookings Institution.

Chetty, Raj, Michael Stepner, Sarah Abraham, Shelby Lin, Benjamin Scuderi, Nicholas Turner, Augustin Bergeron, and David Cutler. 2016. "The Association between Income and Life Expectancy in the United States, 2001-2014." JAMA 315(16): 1750-1766.

Coronado, Julia Lynn, Don Fullerton, and Thomas Glass. 2000. "The Progressivity of Social Security.” Working Paper w7520. Cambridge, MA: National Bureau of Economic Research.

Duggan, James E. and Christopher J. Soares. 2002. "Actuarial Nonequivalence in Early and Delayed Social Security Benefit Claims.” Public Finance Review 30(3): 188-207.

Duggan, James E., Robert Gillingham, and John S. Greenlees. 2007. "Mortality and Lifetime Income Evidence from Social Security Records.” Working Paper 07/15. Washington, DC: International Monetary Fund.

Goss, Stephen C. 1985. "Letter to Daphne Butler on 'Actuarial Fairness' of Benefit Adjustment Factors.” Baltimore, MD: U.S. Social Security Administration.

Gustman, Alan L. and Thomas L. Steinmeier. 2001. "How Effective is Redistribution under the Social Security Benefit Formula?” Journal of Public Economics 82(1): 1-28.

Heiland, Frank and Na Yin. 2014. "Have We Finally Achieved Actuarial Fairness of Social Security Retirement Benefits and Will It Last?” Working Paper 2014-307. Ann Arbor, MI: Michigan Retirement Research Center.

Henderson, John R. 1998. "Demographics of the Titanic Passengers: Deaths, Survivals, Nationality, and Lifeboat Occupancy.” Available at: icyousee.org/titanic.html 
Jivan, Natalia. 2004. "How Can the Actuarial Reduction for Social Security Early Retirement Be Right?" Just the Facts on Retirement Issues 11. Chestnut Hill, MA: Center for Retirement Research at Boston College.

Munnell, Alicia H. and Steven A. Sass. 2012. "Can the Actuarial Reduction for Social Security Early Retirement Still Be Right?" Issue in Brief 12-6. Chestnut Hill, MA: Center for Retirement Research at Boston College.

Myers, Robert J. 1993. Social Security, Fourth Edition. Philadelphia, PA: Pension Research Council, University of Pennsylvania Press.

Shoven, John B. and Sita Nataraj Slavov. 2014a. "Recent Changes in the Gains from Delaying Social Security." Journal of Financial Planning 27(3): 32-41.

Shoven, John B. and Sita Nataraj Slavov. 2014b. "Does It Pay to Delay Social Security?" Journal of Pension Economics \& Finance 13(2): 121-144.

U.S. Social Security Administration. 2010. "Effect of Early or Delayed Retirement on Retirement Benefits.” Washington, DC. Available at: https://www.ssa.gov/oact/ProgData/ar_drc.html

U.S. Social Security Administration. 2019a. The Annual Report of the Board of Trustees of the Federal Old-Age and Survivors Insurance and Federal Disability Insurance Trust Funds. Washington, DC: U.S. Government Printing Office.

U.S. Social Security Administration. 2019b. "Average and Effective Interest Rates." Washington, DC. Available at: https://www.ssa.gov/oact/progdata/annualinterestrates.html

U.S. Social Security Administration. 2019c. "Life Table Functions Based on the Alternative 2 Mortality Probabilities in the 2019 Trustees Report" (unpublished). Washington, DC.

U.S. Social Security Administration. 2019d. Annual Statistical Supplement to the Social Security Bulletin, 2018. SSA Publication No. 13-11700. Washington, DC.

Waldron, Hilary. 2007. "Trends in Mortality Differentials and Life Expectancy for Male Social Security-covered Workers, by Socioeconomic Status." Social Security Bulletin 67(3): 128. 
Table 1. Effect of Claiming Age on Retirement Benefits, by Full Retirement Age

\begin{tabular}{lccc}
\hline \multirow{2}{*}{ Claiming age } & \multicolumn{3}{c}{ Full Retirement Age } \\
\cline { 2 - 4 } & Age 65 & Age 66 & Age 67 \\
\hline 62 & 0.800 & 0.750 & 0.700 \\
63 & 0.867 & 0.800 & 0.750 \\
64 & 0.933 & 0.867 & 0.800 \\
65 & $\mathbf{1 . 0 0 0}$ & 0.933 & 0.867 \\
66 & 1.080 & $\mathbf{1 . 0 0 0}$ & 0.933 \\
67 & 1.160 & 1.080 & $\mathbf{1 . 0 0 0}$ \\
68 & 1.240 & 1.016 & 1.080 \\
69 & 1.320 & 1.240 & 1.016 \\
70 & 1.400 & 1.320 & 1.240 \\
\hline
\end{tabular}

Note: While the delayed retirement credit was between 3-6.5 percent while the Full Retirement Age was 65, factors in this table are adjusted to reflect the ultimate 8-percent per year delayed retirement credit, for simplicity. Source: U.S. Social Security Administration (2010).

Table 2. Current Adjustments and Actuarial Fair Adjustments for New Beneficiaries, 2018

\begin{tabular}{lccc}
\hline Claiming age & $\begin{array}{c}\text { Current } \\
\text { adjustments }\end{array}$ & $\begin{array}{c}\text { Fair } \\
\text { adjustment }\end{array}$ & $\begin{array}{c}\text { Ratio of fair } \\
\text { to current }\end{array}$ \\
\hline 62 & 0.700 & 0.775 & 1.107 \\
63 & 0.750 & 0.812 & 1.083 \\
64 & 0.800 & 0.853 & 1.066 \\
65 & 0.867 & 0.897 & 1.035 \\
66 & 0.933 & 0.946 & 1.014 \\
67 & 1.000 & 1.000 & 1.000 \\
68 & 1.080 & 1.059 & 0.981 \\
69 & 1.160 & 1.125 & 0.970 \\
70 & 1.240 & 1.199 & 0.967 \\
\hline
\end{tabular}

Sources: Authors' calculations using unpublished mortality data from Social Security Actuaries (2019; Social Security Trustees Report (2019); and Table 6.A4 of the Social Security Annual Statistical Supplement (2019). 
Table 3. Costs to Social Security of Outdated Adjustments for New Beneficiaries, 2018

\begin{tabular}{lccccc}
\hline Claiming age & Beneficiaries & $\begin{array}{c}\text { Average } \\
\text { monthly benefit }\end{array}$ & $\begin{array}{c}\text { Actuarially } \\
\text { fair } \\
\text { monthly benefit }\end{array}$ & $\begin{array}{c}\text { Monthly } \\
\text { cost to SS, } \\
\text { per person }\end{array}$ & $\begin{array}{c}\text { Total annual } \\
\text { cost } \\
\text { (millions) }\end{array}$ \\
\hline 62 & 897,713 & $\$ 1,123$ & $\$ 1,244$ & $-\$ 120$ & $-\$ 1,297$ \\
63 & 188,718 & $\$ 1,323$ & $\$ 1,433$ & $-\$ 110$ & $-\$ 249$ \\
64 & 198,914 & $\$ 1,384$ & $\$ 1,476$ & $-\$ 92$ & $-\$ 219$ \\
65 & 318,807 & $\$ 1,566$ & $\$ 1,622$ & $-\$ 56$ & $-\$ 213$ \\
66 & 633,660 & $\$ 1,672$ & $\$ 1,881$ & $-\$ 26$ & $-\$ 195$ \\
67 & 79,248 & $\$ 1,971$ & $\$ 1,971$ & $\$ 0$ & $\$ 0$ \\
68 & 45,955 & $\$ 2,107$ & $\$ 2,067$ & $\$ 40$ & $\$ 22$ \\
69 & 42,040 & $\$ 2,284$ & $\$ 2,216$ & $\$ 68$ & $\$ 34$ \\
70 & 168,358 & $\$ 3,380$ & $\$ 3,268$ & $\$ 112$ & $\$ 226$ \\
\hline Total & $2,573,413$ & & & & $-\$ 1,890$ \\
\hline
\end{tabular}

Notes: Negative costs are gains to Social Security. Data exclude disability conversion.

Sources: Authors' calculations using unpublished mortality data from Social Security Actuaries (2019); Social Security Trustees Report (2019); and Table 6.A4 of the Social Security Annual Statistical Supplement (2019).

Table 4. Relative Mortality Ratios by Age Group for Retired-Worker Beneficiaries, 2015

\begin{tabular}{lcccccc}
\hline $\begin{array}{l}\text { AIME } \\
\text { quintile }\end{array}$ & $62-64$ & $65-69$ & $70-74$ & $75-79$ & $80-84$ & Total \\
\hline \multicolumn{7}{c}{ Male } \\
Lowest & 1.77 & 1.63 & 1.48 & 1.33 & 1.18 & 1.38 \\
Second & 1.18 & 1.15 & 1.18 & 1.16 & 1.13 & 1.15 \\
Middle & 0.86 & 0.91 & 0.97 & 1 & 1.02 & 0.98 \\
Fourth & 0.66 & 0.74 & 0.79 & 0.85 & 0.91 & 0.83 \\
Highest & 0.52 & 0.54 & 0.58 & 0.65 & 0.75 & 0.65 \\
\hline Average & 1.00 & 1.00 & 1.00 & 1.00 & 1.00 & 1.00 \\
\hline Lowest & 1.54 & 1.34 & 1.22 & 1.13 & 1.06 & 1.16 \\
Second & 1.02 & 1.06 & 1.08 & 1.06 & 1.02 & 1.05 \\
Middle & 0.88 & 0.96 & 0.99 & 1.01 & 1.01 & 0.99 \\
Fourth & 0.83 & 0.88 & 0.92 & 0.97 & 1 & 0.96 \\
Highest & 0.73 & 0.75 & 0.78 & 0.84 & 0.91 & 0.84 \\
\hline Average & 1.00 & 1.00 & 1.00 & 1.00 & 1.00 & 1.00 \\
\hline
\end{tabular}

Source: Bosley, Morris, and Glenn (2018). 
Table 5. Lifetime Benefits at Age 62 Per Worker: Constant Mortality vs. Actual Earnings-related Mortality, by Quintile 2018

\begin{tabular}{lccc}
\hline AIME quintile & $\begin{array}{c}\text { Constant } \\
\text { mortality }\end{array}$ & $\begin{array}{c}\text { Earnings-related } \\
\text { mortality }\end{array}$ & Difference \\
\hline Lowest & $\$ 147,288$ & $\$ 133,947$ & $-\$ 13,341$ \\
Second & $\$ 233,426$ & $\$ 224,640$ & $-\$ 8,786$ \\
Average & $\$ 311,049$ & $\$ 311,049$ & $\$ 0$ \\
Fourth & $\$ 421,549$ & $\$ 438,618$ & $\$ 17,070$ \\
Highest & $\$ 512,969$ & $\$ 565,817$ & $\$ 52,848$ \\
\hline Total & $\$ 1,626,281$ & $\$ 1,674,071$ & $\$ 47,790$ \\
\hline
\end{tabular}

Sources: Authors' calculations using Unpublished Mortality Data from Social Security Actuaries (2019); Social Security Trustees Report (2019); and Table 5.B7 of the Social Security Annual Statistical Supplement (2019). 
Table 6. Lifetime Benefits Per Worker by Claiming Age: Constant Mortality vs. Actual Earnings-related Mortality, by Quintile, 2018

\begin{tabular}{lcccccc}
\hline Quintile & Lowest & Second & Average & Fourth & Highest & Total \\
\hline $\begin{array}{l}\text { Constant mortality } \\
\text { (all ages) }\end{array}$ & $\$ 147,288$ & $\$ 233,426$ & $\$ 311,049$ & $\$ 421,549$ & $\$ 512,969$ & $\$ 1,626,281$ \\
62 & $\$ 133,947$ & $\$ 224,640$ & $\$ 311,049$ & $\$ 438,618$ & $\$ 565,817$ & $\$ 1,674,071$ \\
63 & $\$ 133,305$ & $\$ 224,218$ & $\$ 311,049$ & $\$ 439,439$ & $\$ 568,358$ & $\$ 1,676,368$ \\
64 & $\$ 132,661$ & $\$ 223,773$ & $\$ 311,049$ & $\$ 440,270$ & $\$ 571,015$ & $\$ 1,678,767$ \\
65 & $\$ 132,018$ & $\$ 223,303$ & $\$ 311,049$ & $\$ 441,107$ & $\$ 573,796$ & $\$ 1,681,272$ \\
66 & $\$ 131,372$ & $\$ 222,806$ & $\$ 311,049$ & $\$ 441,965$ & $\$ 576,712$ & $\$ 1,683,905$ \\
67 & $\$ 130,719$ & $\$ 222,279$ & $\$ 311,049$ & $\$ 442,843$ & $\$ 579,773$ & $\$ 1,686,663$ \\
68 & $\$ 130,061$ & $\$ 221,719$ & $\$ 311,049$ & $\$ 443,737$ & $\$ 582,984$ & $\$ 1,689,550$ \\
69 & $\$ 129,404$ & $\$ 221,125$ & $\$ 311,049$ & $\$ 444,642$ & $\$ 586,349$ & $\$ 1,692,569$ \\
70 & $\$ 128,754$ & $\$ 220,493$ & $\$ 311,049$ & $\$ 445,550$ & $\$ 589,873$ & $\$ 1,695,719$ \\
\hline
\end{tabular}

Sources: Authors' calculations using Unpublished Mortality Data from Social Security Actuaries (2019); Table 5.B7 of the Social Security Annual Statistical Supplement (2019); and Bosley, Morris, and Glenn (2018). 
Table 7. Total Cost of Lifetime Benefits for All Retired Workers Currently Receiving Benefits by Mortality and Claiming Patterns, in Millions, 2018

\begin{tabular}{lccc}
\hline AIME quintile & $\begin{array}{c}\text { Constant } \\
\text { mortality }\end{array}$ & $\begin{array}{c}\text { Earnings-related } \\
\text { mortality }\end{array}$ & $\begin{array}{c}\text { Earnings-related } \\
\text { mortality and } \\
\text { claiming }\end{array}$ \\
\hline Lowest & $\$ 1,288$ & $\$ 1,149$ & $\$ 1,163$ \\
Second & $\$ 2,041$ & $\$ 1,947$ & $\$ 1,957$ \\
Average & $\$ 2,720$ & $\$ 2,720$ & $\$ 2,720$ \\
Fourth & $\$ 3,686$ & $\$ 3,865$ & $\$ 3,850$ \\
Highest & $\$ 4,486$ & $\$ 5,047$ & $\$ 4,999$ \\
\hline Total & $\$ 14,221$ & $\$ 14,728$ & $\$ 14,688$ \\
\hline
\end{tabular}

Notes: The constant mortality and earnings-related mortality columns assume that workers are equally distributed across all claiming ages. The earnings-related mortality column uses actual claiming patterns by AIME quintile. Sources: Authors' calculations using unpublished mortality data from Social Security Actuaries (2019); Social Security Trustees Report (2019) and; Table 5.B7 of the Social Security Annual Statistical Supplement (2019).

Table 8. Percentage of Total Benefits by Quintile, 2018

\begin{tabular}{lccc}
\hline AIME quintile & $\begin{array}{c}\text { Constant } \\
\text { mortality }\end{array}$ & $\begin{array}{c}\text { Earnings-related } \\
\text { mortality }\end{array}$ & $\begin{array}{c}\text { Earnings-related } \\
\text { mortality and } \\
\text { claiming }\end{array}$ \\
\hline Lowest & $9 \%$ & $8 \%$ & $8 \%$ \\
Second & $14 \%$ & $13 \%$ & $13 \%$ \\
Average & $19 \%$ & $18 \%$ & $19 \%$ \\
Fourth & $26 \%$ & $26 \%$ & $26 \%$ \\
Highest & $32 \%$ & $34 \%$ & $34 \%$ \\
\hline
\end{tabular}

Notes: The constant mortality and earnings-related mortality columns assume that workers are equally distributed across all claiming ages. The earnings-related mortality column uses actual claiming patterns by AIME quintile. Sources: Authors' calculations using unpublished mortality data from Social Security Actuaries (2019); Social Security Trustees Report (2019) and; Table 5.B7 of the Social Security Annual Statistical Supplement (2019). 
Figure 1. Female Cohort Life Expectancy at Age 65, 1956 and 2020

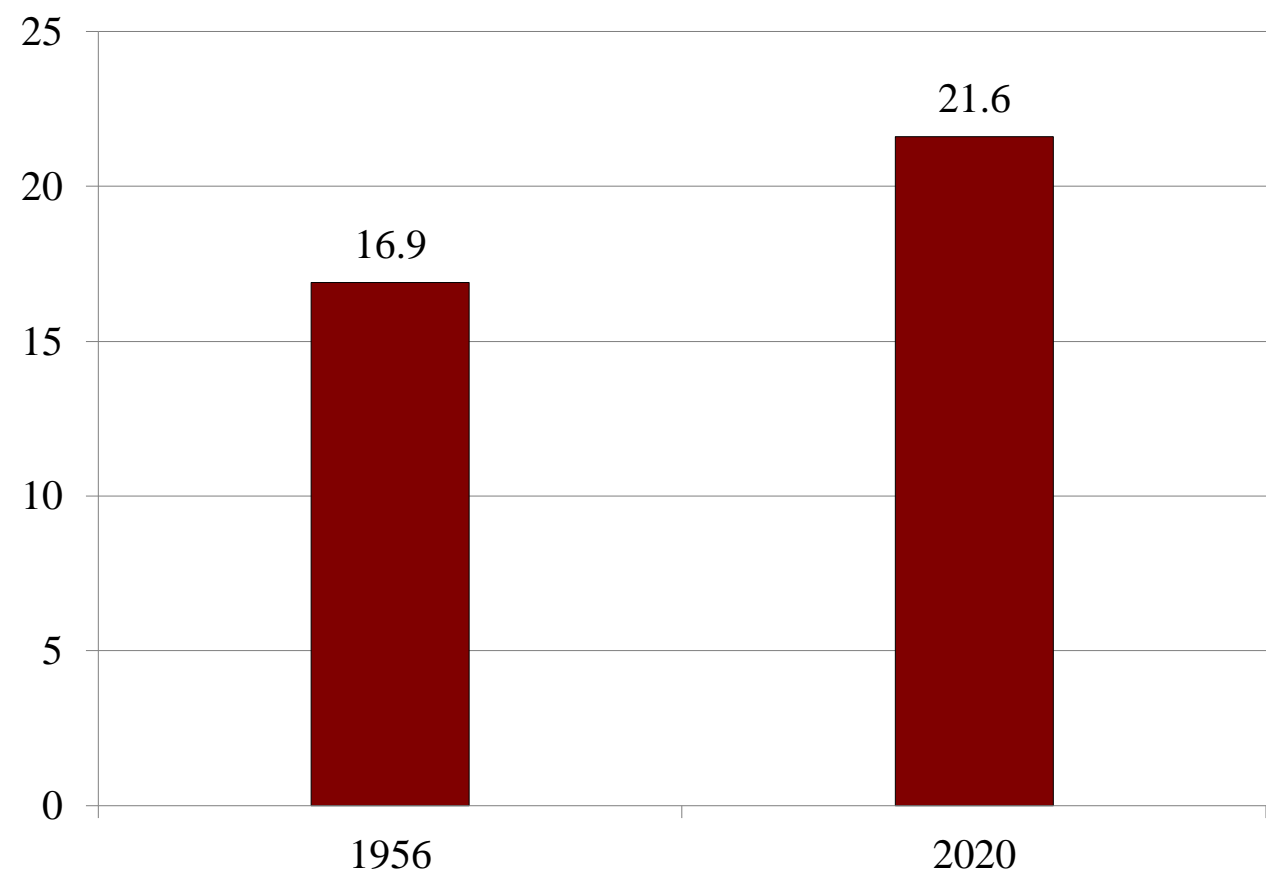

Source: U.S. Social Security Administration (2019).

Figure 2. Real Interest Rates on Special-Issue Treasury Bonds, 1960-2020

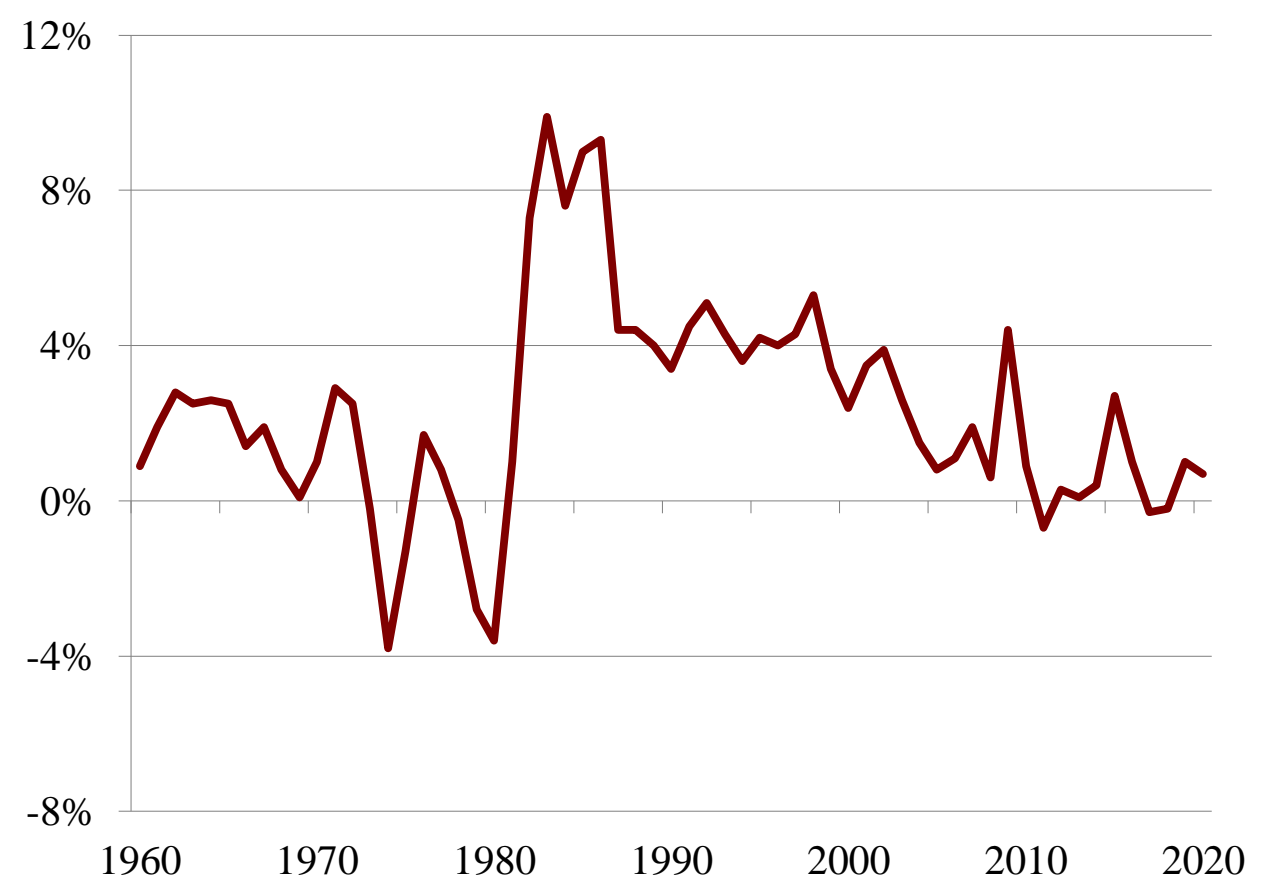

Source: U.S. Social Security Administration (2019a). 
Figure 3. Ratio of Cost of Lifetime Benefits Claimed at Age 62 to Cost of Benefits Claimed at Age 65

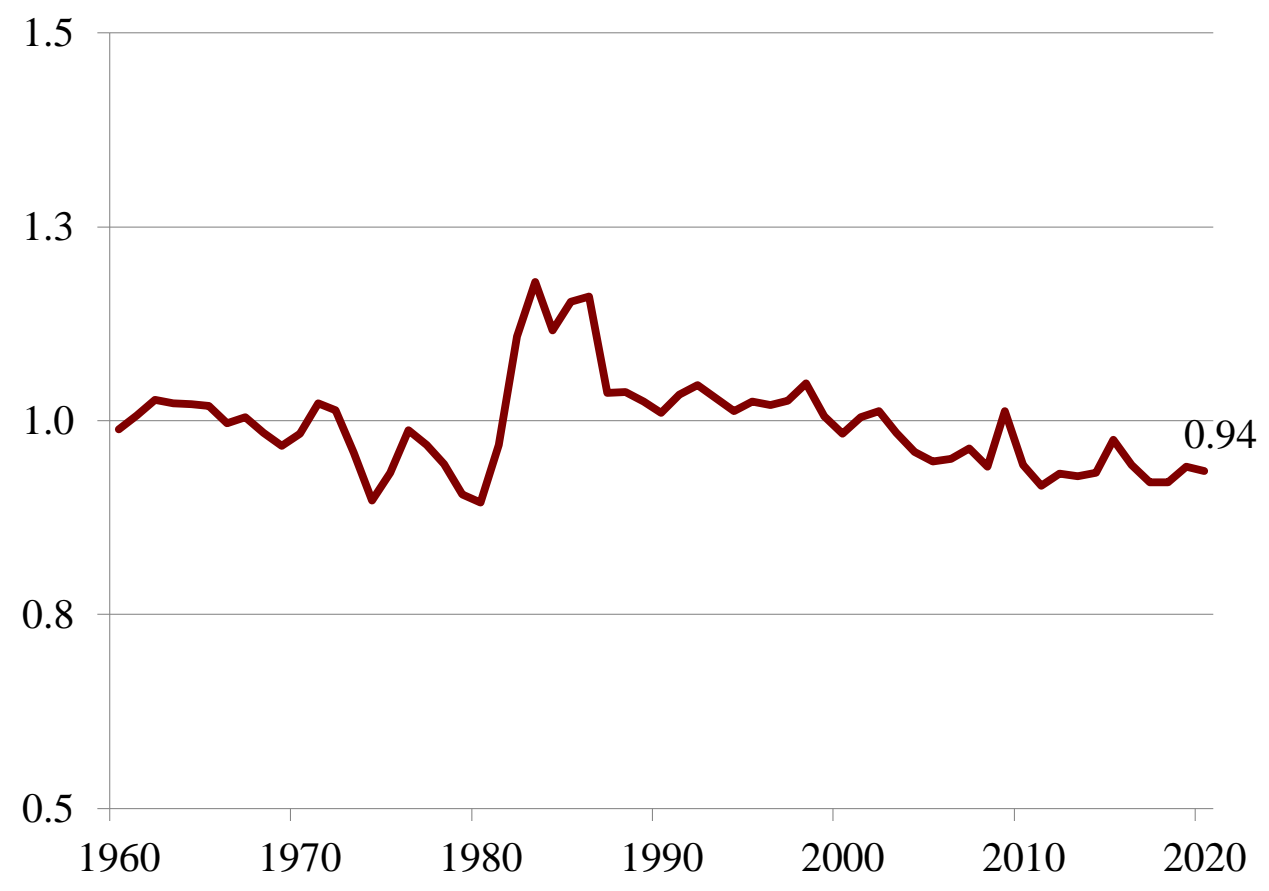

Source: Authors' calculations using data from the U.S. Social Security Administration (2019a,c). 
Figure 4. Ratio of Cost of Lifetime Benefits Claimed at Age 65 to Cost of Benefits Claimed at Age 70

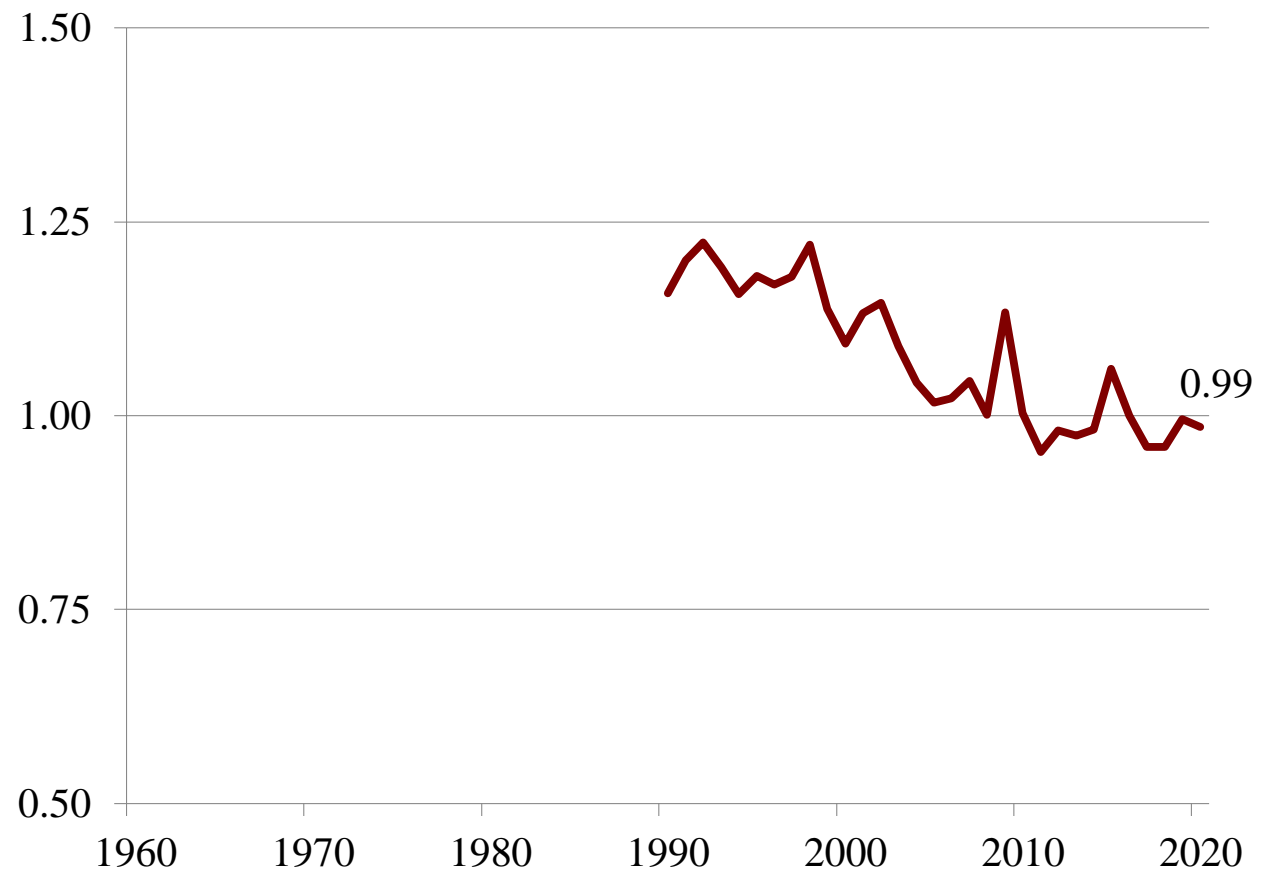

Note: Assumes an 8-percent delayed retirement credit available from 1990 on and the FRA remained at 65. Source: Authors' calculations using data from the U.S. Social Security Administration (2019a, c). 
Figure 5. Ratio of Cost of Lifetime Benefits Claimed at Age 62 to Cost of Benefits Claimed at Age 70 (Assumes Age 67 FRA)

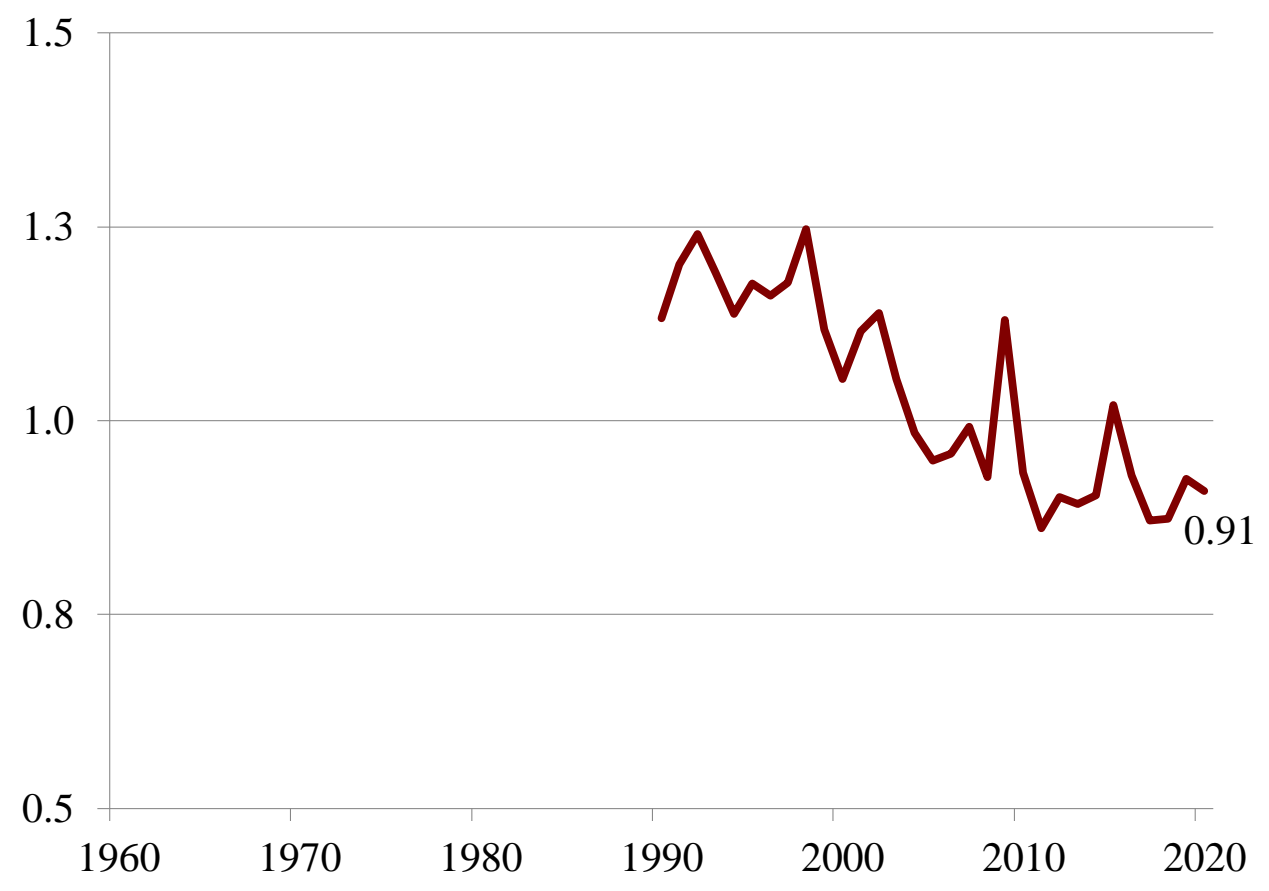

Source: Authors' calculations using data from the U.S. Social Security Administration (2019a, b).

Figure 6. Relative Mortality Ratios for Male Retired Workers, Ages 62-64

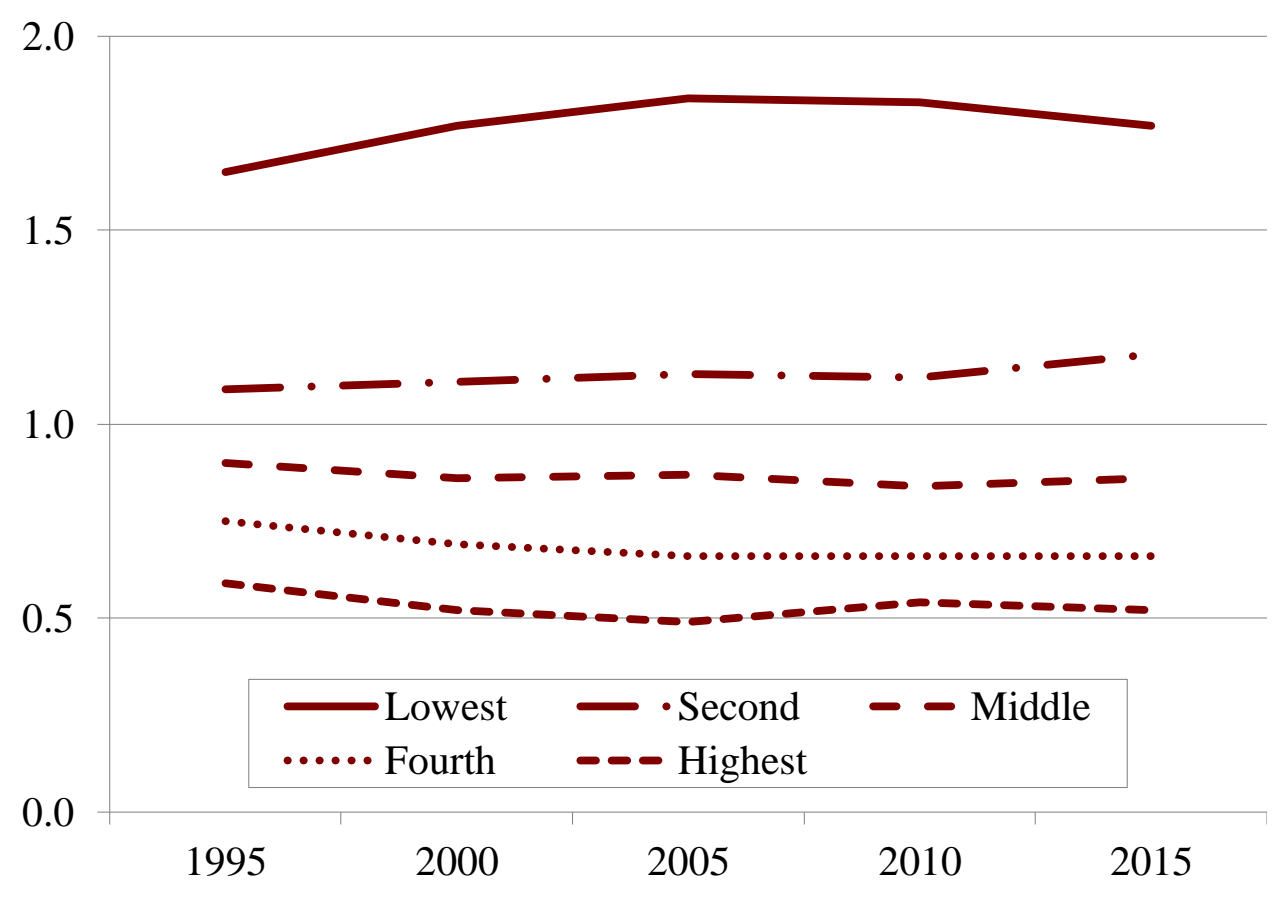

Source: Bosley, Morris, and Glenn (2018). 
Figure 7. Estimated Life Expectancy at Age 62, 1995-2015

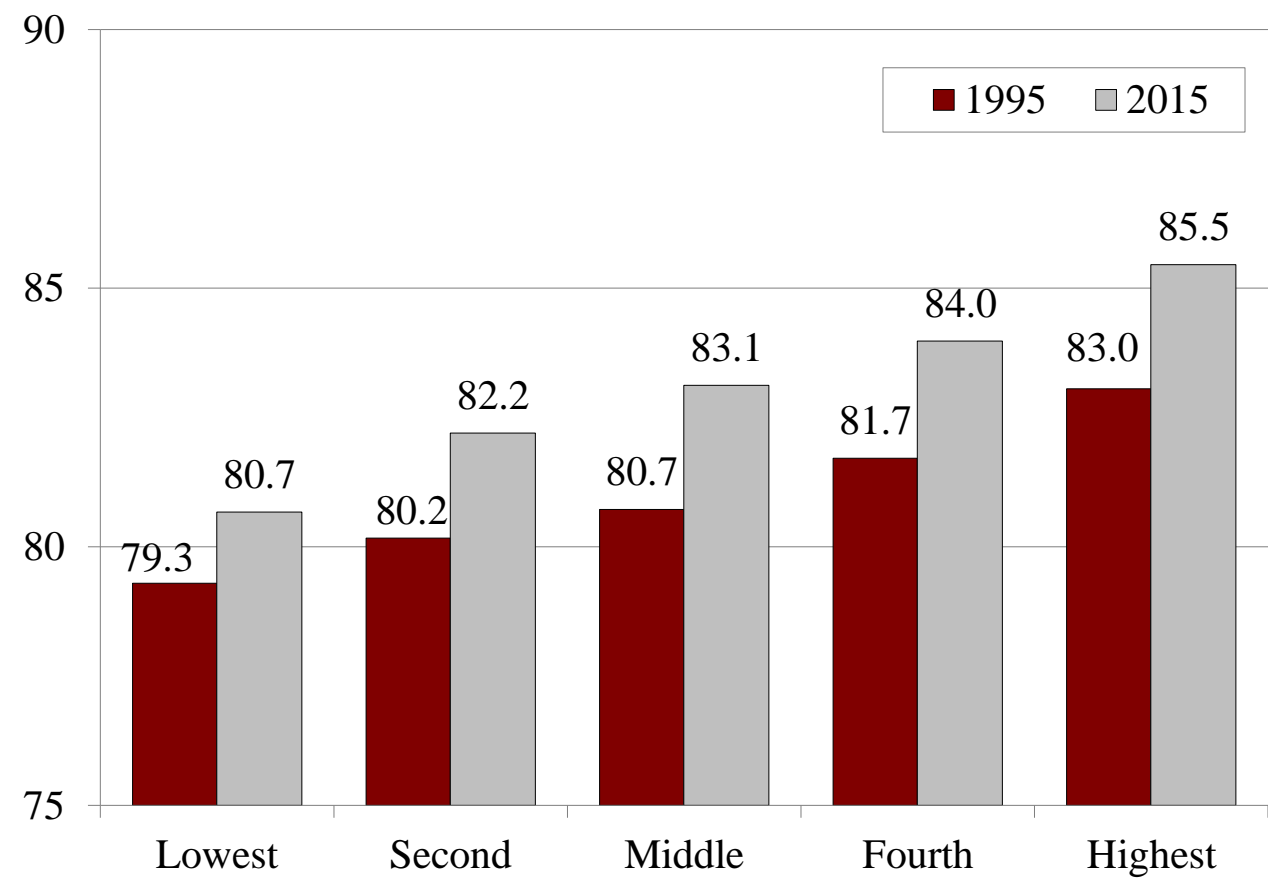

Note: Estimates assume a linear mortality trend for years without data and that mortality rates remain constant after age 80 , the last age of available data.

Source: Authors' calculations from Bosley, Morris, and Glenn (2018).

Figure 8. Relative Mortality Ratios for Male Retired Workers, Ages 70-74

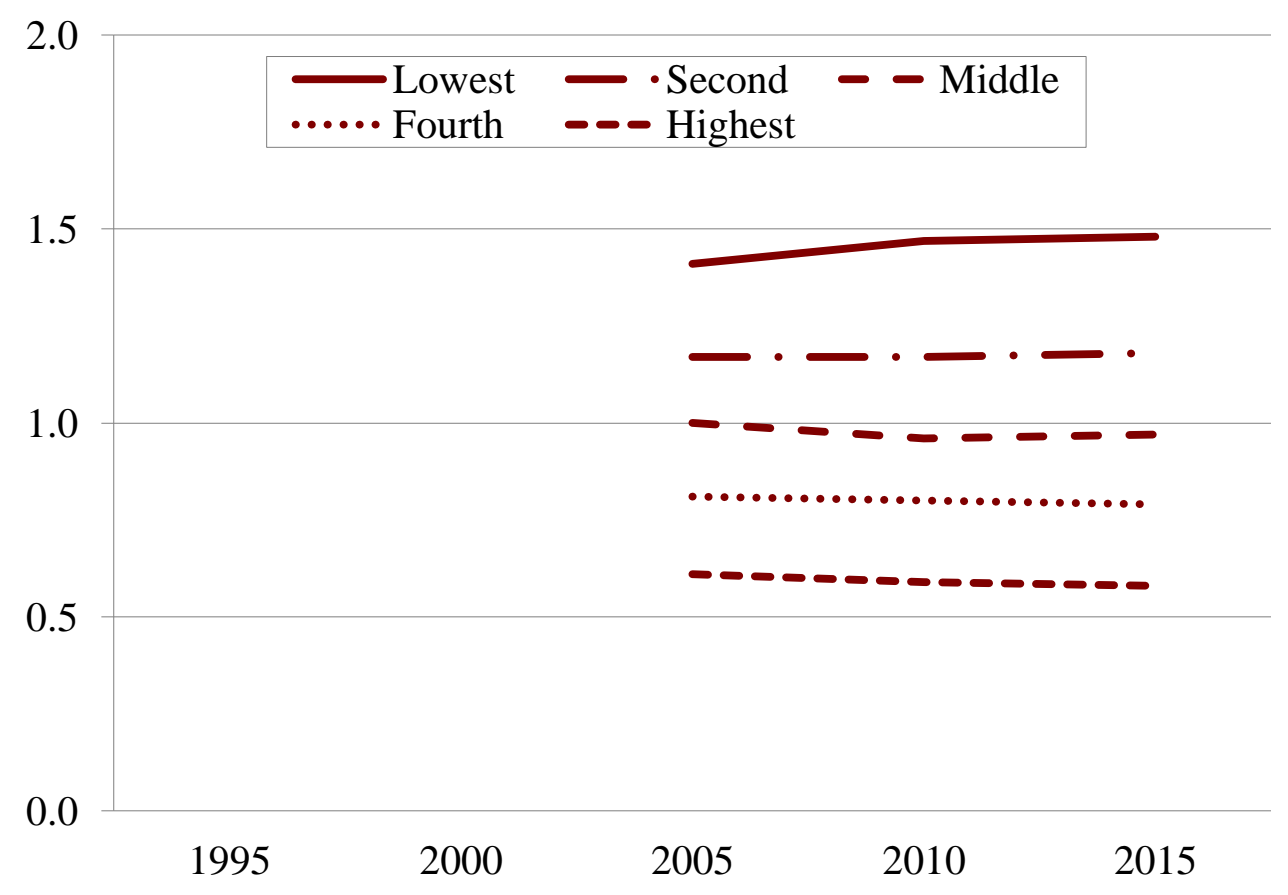

Source: Bosley, Morris, and Glenn (2018). 
Figure 9. Claiming Age by AIME Quintile of Workers Turning 62 between 1995-2004

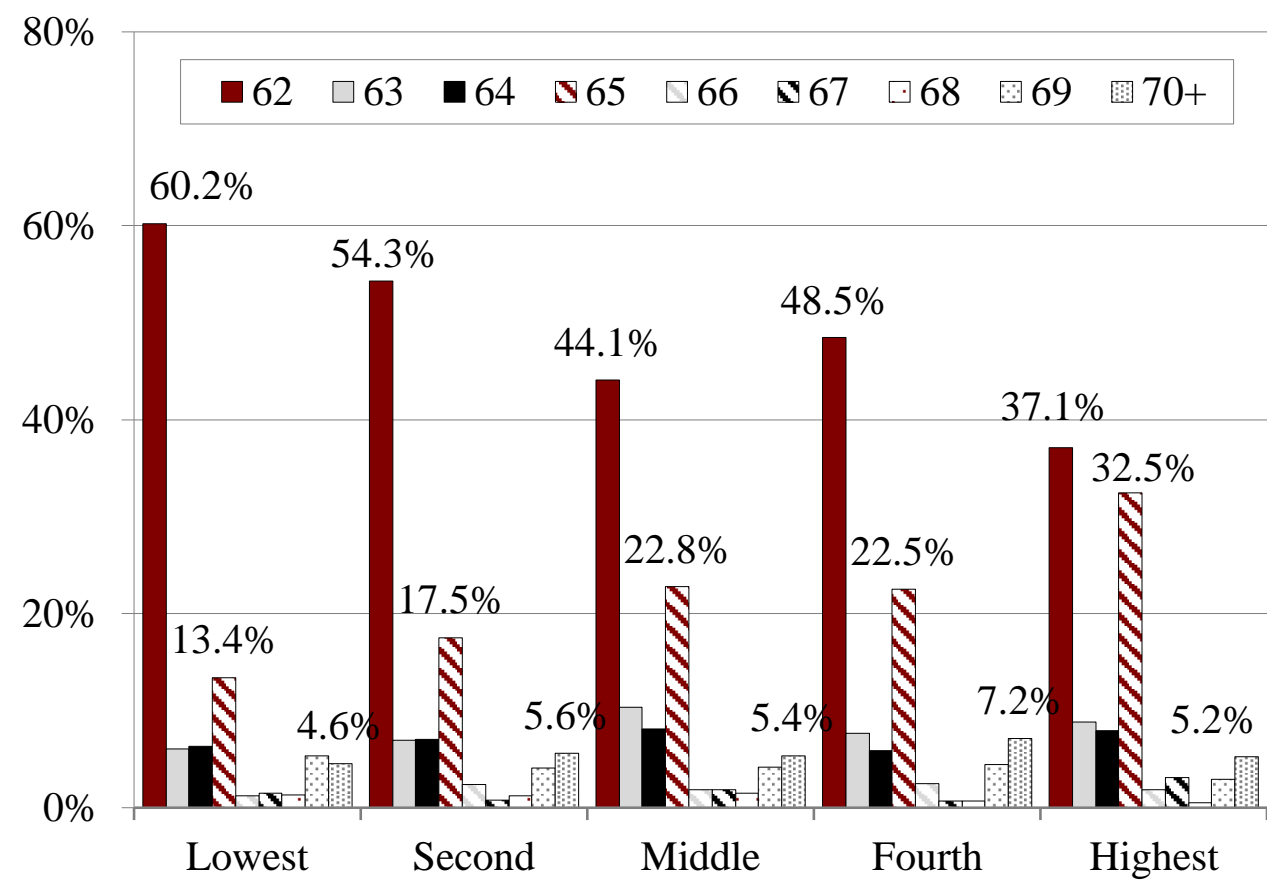

Note: Results are for cohorts born between 1933 and 1942 to align with mortality data from Bosley, Morris, and Glenn (2018).

Source: Authors' calculations from HRS linked to Administrative Benefits data. 


\section{Appendix}

Table A1. Current and Actuarially Fair Adjustments Under Different Long-Run Interest Rate Assumptions

\begin{tabular}{lcccccccc}
\hline \multirow{2}{*}{ Claiming age } & $\begin{array}{c}\text { Current } \\
\text { Adjustments }\end{array}$ & $0.0 \%$ & $0.5 \%$ & $1.0 \%$ & $1.5 \%$ & $2.0 \%$ & $2.5 \%$ & $3.0 \%$ \\
\cline { 3 - 8 } & 0.70 & 0.77 & 0.76 & 0.75 & 0.74 & 0.72 & 0.71 & 0.70 \\
62 & 0.75 & 0.81 & 0.80 & 0.79 & 0.78 & 0.77 & 0.76 & 0.75 \\
63 & 0.80 & 0.85 & 0.84 & 0.83 & 0.83 & 0.82 & 0.81 & 0.80 \\
64 & 0.87 & 0.90 & 0.89 & 0.88 & 0.88 & 0.87 & 0.87 & 0.86 \\
65 & 0.93 & 0.95 & 0.94 & 0.94 & 0.94 & 0.93 & 0.93 & 0.93 \\
66 & 1.00 & 1.00 & 1.00 & 1.00 & 1.00 & 1.00 & 1.00 & 1.00 \\
67 & 1.08 & 1.06 & 1.06 & 1.07 & 1.07 & 1.07 & 1.08 & 1.08 \\
68 & 1.16 & 1.13 & 1.14 & 1.14 & 1.15 & 1.16 & 1.17 & 1.17 \\
69 & 1.24 & 1.20 & 1.21 & 1.23 & 1.24 & 1.25 & 1.26 & 1.28 \\
70 & & & & & & & & \\
\hline
\end{tabular}

Sources: Authors' calculations using unpublished mortality data from Social Security Actuaries (2019); and Social Security Trustees Report (2019). 


\section{RECENT WORKING PAPERS FROM THE CENTER FOR RETIREMENT RESEARCH AT BOSTON COLLEGE}

Intended Bequests and Housing Equity in Older Age

Gary V. Engelhardt and Michael D. Eriksen, January 2021

The Effect of Early Claiming Benefit Reduction on Retirement Rates

Damir Cosic and C. Eugene Steuerle, January 2021

Financial Security at Older Ages

Barbara A. Butrica and Stipica Mudrazija, December 2020

Do People Work Longer When They Live Longer?

Damir Cosic, Aaron R. Williams, and C. Eugene Steuerle, December 2020

Do State and Local Government Employees Save Outside of Their Defined Benefit Plans When They Need To?

Laura D. Quinby and Geoffrey T. Sanzenbacher, November 2020

How Much Taxes Will Retirees Owe on Their Retirement Income?

Anqi Chen and Alicia H. Munnell, November 2020

A Behavioral Economics Assessment of SSDI Earnings Reporting Documents

Denise Hoffman, Jonah Deutsch, and Britta Seifert, November 2020

How Accurate Are Retirees' Assessments of Their Retirement Risk?

Wenliang Hou, July 2020

Is Nontraditional Work at Older Ages Associated with Better Retirement Security? Matthew S. Rutledge and Gal Wettstein, July 2020

New Insights on Self-Employment of Older Adults in the United States Joelle Abramowitz, July 2020

What Jobs Do Employers Want Older Workers to Do?

Alicia H. Munnell, Gal Wettstein, and Abigail N. Walters, June 2020

Technological Innovation and Labor Income Risk

Leonid Kogan, Dimitris Papanikolaou, Lawrence D. W. Schmidt, and Jae Song, June 2020

Are Older Nontraditional Workers Able to Find Health and Retirement Coverage? Matthew S. Rutledge, March 2020

All working papers are available on the Center for Retirement Research website (https://crr.bc.edu) and can be requested by e-mail (crr@bc.edu) or phone (617-552-1762). 